\title{
1 The genomic sequence and comparative genomic analysis of 2 cultivated passion fruit(Passiflora edulis L.)
}

3 Yanyan $\mathrm{Wu}^{1}$, Qinglan $\operatorname{Tian}^{1}$, Jieyun $\mathrm{Liu}^{1}$, Yongcai Huang ${ }^{1}$, Weihua Huang ${ }^{1}$, Xiuzhong

$4 \mathrm{Xia}^{2}$, Haifei Mou ${ }^{1}$, Xinghai Yang ${ }^{2 *}$

$5 \quad{ }^{1}$ Biotechnology Research Institute, Guangxi Academy of Agricultural Sciences,

6 Nanning, China

$7 \quad{ }^{2}$ Rice Research Institute, Guangxi Academy of Agricultural Sciences, Nanning, China

8 Corresponding author: Xinghai Yang; Department/Institute: Rice Research

9 Institute, Guangxi Academy of Agricultural Sciences; Address: 174 East Daxue Road,

10 Nanning, Guangxi, 530007: E-mail: yangxinghai514@163.com; Tel: +867713244040 
24 Abstract: Cultivated passion fruit is a fruit tree widely cultivated in southern China,

25 but little is known about its genomics, which seriously restricts the molecular genetics

26 research of passion fruit. In this study, we analyzed the $165.7 \mathrm{Mb}$ representative

27 genome sequences. The results showed that the passion fruit genome contained a large

28 number of simple sequence repeats (SSR). Compared to the cassava and peach

29 genomes, the passion fruit genome has 23,053 predicted genes. These genes can be

30 aligned to 282 plant genomes. GO annotation indicated that these genes are involved in

31 metabolic pathways of carbohydrates, organic acids, lipids and other molecules. KEGG

32 pathway enrichment assigned these genes into five major categories and 19 secondary

33 functions. Cluster analysis of gene families showed that 12,767 genes could be

34 clustered into 9,868 gene families and 291 unique gene families. On the evolutionary

35 relationship, the passion fruit is closely related to Populus trichocarpa and Ricinus

36 communis, but the rate of evolution is slower. In summary, this genomic analysis result

37 is informative, and will facilitate the future studies on gene functions of passion fruit.

38 Keywords: cultivated passion fruit (Passiflora edulis L.); genome; gene annotation;

39 phylogenetic evolution; bioinformatics

40 1. Introduction

41 There are more than 530 species of passion fruit, and the most widely cultivated 42 species is Passiflora edulis, which belongs to the Theoideae suborder, Passifloraceae 43 family, and Passiflora L. genus [1]. Passion fruit has really high contents of nutrition, 44 including sugar, fat, protein, vitamins and mineral elements [2,3]。

45 In eukaryotes, the genome is the entire genetic material of a single set of 46 chromosomes in the species. Each cell of a plant contains three distinct genomes: 47 nuclear genome, mitochondrial genome, and plastid genome. Currently, studies are 48 mainly focused on the nuclear genome. Chromosomes are gene carriers, and the gene 49 functions are closely related to the structural components on chromosomes. Genome 50 sequencing can help us better understand the functions and evolution of plant 51 genes.Currently, the genome sequencing study on passion fruit is still focused on the 
52 development of molecular markers. Cerqueira-silva et al. [4] developed 69 pairs of SSR

53 primers using two passion fruit genome microsatellite-enriched libraries. Santos et al.

54 [5] used BAC end sequencing method to obtain 6,194,248 bp of passion fruit genome

55 data, in which 669 microsatellite sequences were found, with an average of one SSR per

$569.25 \mathrm{~kb}$ genome sequence. Later, Araya et al. [6] developed 816 pairs of SSR primers in

57 the structural and functional regions using parts of the passion fruit genome sequence.

58 The results showed that $53.2 \%$ of SSR primers were polymorphic. Recently, Costa et al.

59 [7] sequenced the cDNA of Xanthomonas infected passion fruit, and developed the

60 functional SSR and SNP markers.

61 With the rapid development of High-throughput sequencing, nearly 200 plants

62 have been sequenced. In May 2017, the Beltsville Agricultural Research Center

63 performed genome-wide sequencing on passion fruit CGPA1 using Illumina GAII

64 sequencing technology, and assembled the sequencing results to the Scaffold level.

65 However, they did not conduct genome analysis on these results. In this study, we

66 performed genome annotation and comparative genomic analysis on passion fruit

67 genome. Our results will facilitate the further studies on molecular mechanisms of

68 passion fruit, and also provide references for the scientific development and efficient

69 utilization of passion fruit.

70 2. Materials and Methods

$71 \quad$ 2.1. Genomic Sequence of Passion Fruit

72 The passion fruit genome was uploaded to NCBI

73 (https://www.ncbi.nlm.nih.gov/assembly/GCA_002156105.1/\#/st) by the Beltsville

74 Agricultural Research Center.

75 2.2. Genome Annotation of Passion Fruit

76 Identification of autonomous DNA transposon: The known autonomous DNA

77 transposons in plants, such as Arabidopsis, were collected from public databases

78 (Swiss-Prot and Repbase). Then, the transposons in passion fruit were identified by the

79 software detectMITE [8]. 
Gene structure prediction: Homologous prediction was conducted by comparing the protein coding sequence of a known homologous species with the genomic sequence of a new species (the number of homologous species is no more than 5). The gene structures of new species were predicted by softwares such as BLAST (http:// blast.ncbi.nlm.nih.gov/Blast.cgi), GeneWise [9], etc. De novo prediction used the software depending on statistical characteristics of genomic sequence data to predict gene structure. The commonly used software includes Augustus [10], Glimmer HMM [11], SNAP (http://homepage. Mac.com/iankorf/), etc. After performing the gene structure prediction, the results were combined with the transcriptome alignment data; then, these data were integrated by the EVidenceModeler software

90 (http://evidencemodeler.sourceforge.net/) to generate a non-redundant, more complete 91 gene set. Finally, the EVM annotation results were corrected using PASA 92 (http://pasa.sourceforge.net/) and the transcriptome assembly data. The information such as UTR and variable cutting sites was added to obtain the final gene set.

94 Gene function annotation: The gene set obtained by gene structure annotation was 95 compared with a known protein database by comparison software, in order to obtain the 96 gene function information. The commonly used protein databases include SwissProt

97 (http://www.uniprot.org/), KEGG (http://www.genome.jp/kegg/), InterPro 98 (https://www.ebi.ac.uk/interpro), NR (ftp://ftp.ncbi.nlm.nih.gov/blast/db/) and GO 99 (http://www.geneontology.org/).

100 2.3. Gene Family and Phylogenetic Tree

101 Gene family identification: The software OthoMCL[12] was used. The default e 102 value was 1e-5 and the expansion coefficient was 1.5.

103 Phylogenetic analysis: The software MUSCLE [13] was used to compare different 104 gene families. The sequence alignment results went through jModelTest/ProTest [14] 105 software to find the optimal sequence substitution model. Then, the phylogenetic tree of 
1069 species was constructed by PhyML software [15] using the maximum likelihood

107 method.

108 3. Results

109 3.1. Assembly of Passion Fruit Genome

110 The research group at Beltsville Agricultural Research Center used Illumina GAII

111 technology to sequence the passion fruit CGPA1 genome. The average sequencing

112 depth was $4.5 \times$, with $225,293,527$ reads in total. Finally, $165,656,733$ bp of passion

113 fruit genome sequence was obtained, with 235,883 Contig (Contig N50 was 1,303 bp,

114 Contig L50 was 30,212 bp) and 234,012 scaffolds (Scaffold N50 was 1,311 bp,

115 Scaffold L50 was 30,081 bp). The GC content of the genome was $38.6 \%$.

116 3.2. Repeated Sequence Annotation

117 The SSR Search software [16] and homologous annotation were used to annotate

118 the repeated sequences in passion fruit genome. The results showed that there were 119 428,294 full-type SSR and 1,544,549 incomplete- and composite-type SSR [6]. For

120 transposons, there were 59 Mutator transposons, 41 EnSpm transposons, 49 hAT

121 transposons, 221 PIF transposons, and 2 MLE transposons.

122 3.2. Gene Annotation and Functional Enrichment Analysis of Passion Fruit Genome

123 Genetic structure prediction was conducted using homologous prediction and De

124 novo prediction. Using BLAST, GeneWise, and other alignment softwares, the

125 genomic sequence of passion fruit was compared with the coding sequences of known

126 homologous species Manihot esculenta [17] and Prunus persica [18] to predict the

127 gene structures in passion fruit genome. These prediction results were then combined

128 with the transcriptome alignment data, and all the gene sets predicted by different

129 methods were integrated by the EvidenceModeler software to generate a non-redundant

130 and more complete gene set. Finally, the EVM annotation results were corrected using

131 PASA and transcriptome assembly results. The information such as UTR and variable

132 cutting sites were added, and 23053 genes were eventually predicted. 
133 The gene set obtained by gene structure prediction was blasted in NR, SwissPort,

134 KEGG, InterPro, Pfam and GO databases, and the gene annotation information was

135 shown in Table 1. In KEGG database, the passion fruit genome had 16,835 genes

136 annotated. The gene length was 61-6994 bp, with an average of $670 \mathrm{bp}$. The total length

137 of annotated genes was $11,784,169 \mathrm{bp}$, accounting for $7.1 \%$ of the whole genome. The

138 predicted passion fruit genes can be mapped to the genomes of 282 plant species.

139 Among these genes, 3,015 of them were aligned to the Populus trichocarpa genome,

1402058 genes were mapped to the Jatropha curcas genome, 1,644 genes were aligned to

141 the Ricinus communis genome, 630 genes were mapped to the Theobroma cacao

142 genome [19], and 572 genes were aligned to the Vitis vinifera genome [20].

143 GO analysis was used to classify the functions of annotated genes into categories

144 of Biological process, Cellular component and Molecular Function; then, these

145 functions were further refined into 41 secondary functions (Figure 1). In the Biological

146 process category, there were more genes involved in cellular process (GO: 0009987)

147 and metabolic process (GO: 0008152), accounting for 4,689 and 5,047 genes,

148 respectively; in the Cellular component category, more genes were involved in cell part

149 (GO:0044464) and cell (GO: 0005623), both of which included 1,542 genes; in the

150 Molecular Function category, the catalytic activity (GO: 0003824) and structural

151 molecule activity (GO: 0005198) included more genes, accounting for 5,018 and 5,595,

152 respectively. Since passion fruit has a pleasant aromatic odor and has high contents of

153 sugar, fat, protein, vitamins and minerals [2,3], we focused our study on the metabolic

154 processes of carbohydrates, organic acids, lipids, etc., and found that 1,356 genes were

155 involved in the metabolism of aromatic compounds.

156 In living organisms, different genes were coordinated to perform biological

157 functions. The same actions between different genes form a pathway, and the

158 pathway-based analysis is helpful for further interpreting the gene functions. KEGG

159 database was used to analyze the gene pathways, and the results showed that the gene 
160 pathways were divided into five categories according to the pathway type (Figure 2): A:

161 Cellular Processes; B: Environmental Information Processing; C: Genetic Information

162 Processing; D: Metabolism; E: Organismal Systems. These five categories can be

163 subdivided into 19 secondary functional classes. Among the 1,1325 genes, $61.6 \%$ were

164 associated with metabolic pathways, and the largest group was related to carbohydrate

165 metabolism. Glucose, sucrose, starch and cellulose are the main forms of carbohydrates.

166 Studies have shown that passion fruit is rich in sugars and fats [2,3]. In the passion fruit

167 genome, there were only 570 genes involved in environmental adaptation, suggesting

168 that passion fruit may be less capable to resist biological or non-biological stresses.

169 3.3. Gene Family and Phylogenetic Analysis

170 Based on the passion fruit genome annotation results and the previous studies [1,5],

171 we performed gene family analysis using another nine species, which were Actinidia

172 chinensis [21], Theobroma cacao [19], Vitis vinifera [20], Arabidopsis thaliana

173 [22], Populus euphratica [23], Prunus persica [18], Ricinus communis [24], and Oryza

174 sativa L. ssp. japonica [25]. The number of aligned genes in each species is shown in

175 Table 2. Via cluster analysis of gene families, we found 12,767 genes of passion fruit

176 could be clustered into 9868 gene families, with an average of 1.29 genes per family.

177 Moreover, there were 291 gene families that were unique for passion fruit (Figure 3).

178 Referring to the study from Santos et al. [5], we selected the genomes from

179 Actinidia chinensis [21], Theobroma cacao [19], and Vitis vinifera [20] to perform

180 homologous analysis with the predicted genes of passion fruit (Figure 4). The results

181 showed that Theobroma cacao had the most homologous genes with passion fruit.

182 Using Oryza sativa L. ssp. japonica genome as the reference, we also did phylogenetic

183 analysis on the nine species with homologous genes (Figure 5). The cluster analysis

184 showed that the monocots were clearly separated from the dicots. Also, passion fruit

185 was evolutionarily closer to Populus trichocarpa and Ricinus communis, but the 186 evolution rate was slow. 
187

188

189

190

191

192

193

194

195

196

197

198

199

200

201

202

203

204

205

206

207

208

209

210

211

212

213

\section{Discussion}

The passion fruit genome is rich in repetitive elements, which can be used to develop molecular markers. In our previous study, We identified 13,104 perfect SSRs in the 165.6 Mb of cultivated passion fruit genome. Then we developed 12,934 pairs of SSR primers using a full-type SSR, and the SSR marker showed good polymorphism [16]. According to the different transposon vectors, transposons can be divided into two types: retrotransposons (Class I) and DNA transposons (Class II). The former is mediated by RNA and the latter is mediated by DNA. MITEs (Miniature Inverted Repeat Transposable Elements) are a special class of non-autonomous DNA transposons that are distributed in high-copy form in the genome of plants. The MITEs transposon marker developed by MITEs can only amplify two bands in general, and the PCR product can be efficiently isolate by conventional agarose gel electrophoresis, so the marker is highly efficient and co-dominant molecular marker. We used softwares to identify the MITEs transposon of the cultivated passion fruit genome, and obtained 372 transposons and their flanking sequences, which was important for the development of MITEs markers.

The $165.7 \mathrm{Mb}$ of passion fruit genome sequence was used to perform gene annotation with homologous species Manihot esculenta [17] and Prunus persica [18], and a total of 23,053 genes were predicted. The passion fruit genome size is 1,230 Mb [26], and the genome size involved in this study is approximately $13.5 \%$ of the total genome length. Therefore, we need to assemble the passion fruit genome to a higher level using high-throughput sequencing, especially at the chromosomal level, is particularly important.

By comparing the predicted protein sequences of passion fruit genome with the known protein sequences, we found that there were more genes related to carbohydrate metabolism, consistent with the fact that passion fruit is rich in sugar, fat, protein, vitamins and mineral elements [2,3]. However, there were less genes involved in 
214 environmental adaption in passion fruit genome, indicating that passion fruit may have

215 poor capability to resist biological or non-biological stresses. At present, the main

216 diseases of passion fruit are viral diseases, bacterial diseases and fungal diseases,

217 among which fungal stem rot is particularly serious.

218 The comparison between passion fruit genome and the genomes of other eight

219 species showed that only a few genes were unique in passion fruit. The unique family

220 mainly contain genes of unkwnown functional proteins, retrovirus-related Pol

221 polyprotein, zinc finger domain $(\mathrm{CH} 2 \mathrm{H} 2)$ proteins, and putative ribonuclease $\mathrm{H}$ protein.

222 A number of genes are associated with retrovirus, which may suggest an important

223 cause of the serious occurrence of viral disease in passion fruit. Specific regulatory

224 sequences on DNA can bind to the corresponding regulatory proteins (transcription

225 factors) and promote the initiation of transcription. In the unique family of passion

226 fruit, the transcription factor family contains many genes, which may indicate that

227 rich gene expression patterns are necessary for the continuous adaptation of passion

228 fruit to the environment and to adjust its growth and metabolism.Moreover, in the

229 evolutionary relationship, passion fruit is closer to Populus trichocarpa [23] and

230 Ricinus communis [24], but the evolution rate is slower.

\section{ACKNOWLEDGMENTS}

232 We thank Beltsville Agricultural Research Center. This work was supported by

233 the Guangxi Natural Science Foundation of China (2018GXNSFBA281024,

234 2018GXNSFAA138124) and Guangxi Academy of Agricultural Sciences

235 (2018YT19).

\section{DATA ACCESSIBILITY}

237 All sequence data are gained from Genome Information for Passiflora edulis

238 (BioProjects: PRJNA371406). 
241

242

243

244

245

246

247

249

250

251

252

253

254

255

256

257

258

259

260

261

262

263

264

265

266

267

268

269

\section{AUTHOR CONTRIBUTIONS}

X.H., Yang, Y.Y., Wu contributed to study design, Q.L., Tian, J.Y., Liu, Y.C., Huang, W.H., Huang contributed to data analysis, X.Z., Xia, H.F., Mou contributed to make tables and figures. All authors read and approve the paper.

\section{COMPETING INTERESTS}

The authors declare that they have no competing interests.

\section{References}

1. Munhoz,C.F.; Costa,Z.P.; Cauz-santos,L.A.; Reátegui,A.; Rodde,N.; Cauet,S.;

Dornelas,M.C.; Leroy,P.; Varani,A.M.; Bergès,H.; Vieira,M. A gene-rich fraction analysis of the Passiflora edulis genome reveals highly conserved microsyntenic regions with two related Malpighiales species. Sci Rep. 2018, 8, 13024.

2. Usda. Passion-fruit. National Nutrient Database for Standard Reference Legacy Release. 2018, 4, 09231.

3. Usda. Passion-fruit juice. National Nutrient Database for Standard Reference. 2018, 4, 09233.

4. Cerqueira-silva,C.B.; Santos,E.S.; Vieira,J.G.; Mori,G.M.; Jesus,O.N.; Corrêa,R.X.; Souza,A.P. New microsatellite markers for wild and commercial species of Passiflora (Passifloraceae) and cross-amplification. Appl Plant Sci. 2014, 2, 1300061.

5. Santos,A.A.; Ha,P.H.; Bellec,A.; Munhoz,C.F.; Pedrosa-harand,A.; Bergès,H.; Vieira,M.L. Begin at the beginning: A BAC-end view of the passion fruit (Passiflora) genome. BMC Genomics. 2014, 15, 816.

6. Araya,S.; Martins,A.M.; Junqueira,N.; Costa,A.M.; Faleiro,F.G.; Ferreira,M.E. Microsatellite marker development by partial sequencing of the sour passion fruit genome (Passiflora edulis Sims). BMC Genomics. 2017, 18, 549.

7. Costa,Z.D.; Munhoz,C.F.; Vieira,M. Report on the development of putative functional SSR and SNP markers in passion fruits. BMC Res Notes. 2017, 10, 445.

8. Ye,C.; Ji,G.; Liang,C. detectMITE: A novel approach to detect miniature inverted repeat transposable elements in genomes. Sci Rep. 2016, 6, 19688.

9. Birney,E.; Clamp,M.; Durbin,R. GeneWise and Genomewise. Genome Res. 2004, 14, 
270

271

272

273

274

275

276

277

278

279

280

281

282

283

284

285

286

287

288

289

290

291

292

293

294

295

296

297

298

299

300

301

302

988-995.

10. Stanke,M.; Keller,O.; Gunduz,I.; Hayes,A.; Waack,S.; Morgenstern,B. AUGUSTUS: ab initio prediction of alternative transcripts. Nucleic Acids Res. 2006, 34, W435-W439.

11. Majoros,W.H.; Pertea,M.; Salzberg,S.L. TigrScan and GlimmerHMM: two open source ab initio eukaryotic gene-finders. Bioinformatics. 2004, 20, 2279-2878.

12. Li,L.; Stoeckert,C.J.; Roos,D.S. OrthoMCL: identification of ortholog groups for eukaryotic genomes. Genome Res. 2003, 13, 2178-2189.

13. Edgar,R.C. MUSCLE: multiple sequence alignment with high accuracy and high throughput. Nucleic Acids Res. 2004, 32, 1792-1797.

14. Posada,D. jModelTest: phylogenetic model averaging. Mol Biol Evol. 2008, 25, $1253-1256$.

15. Guindon,S.; Gascuel,O. A simple, fast, and accurate algorithm to estimate large phylogenies by maximum likelihood. Syst Biol. 2003, 52, 696-704.

16. Wu,Y.Y.; Tian,Q.L.; Liu,J.Y.; Huang,Y.C.; Huang,W.H.; Xia,X.Z.; Yang,X.H.; Mou,H.F. High-throughput Identification and Marker Development of Perfect SSR for Cultivated Genus of Passion Fruit (Passiflora edulis). Molecular Plant Breeding. 2018, 9, 92-96.

17. Bredeson,J.V.; Lyons,J.B.; Prochnik,S.E.; Wu,G.; Ha,C.M.; Edsinger-gonzales,E.; Grimwood,J.; Schmutz,J.; Rabbi,I.Y.; Egesi,C.; Nauluvula,P.; Lebot,V.; Ndunguru,J.; Mkamilo,G.; Bart,R.S.; Setter,T.L.; Gleadow,R.M.; Kulakow,P.; Ferguson,M.E.;

Rounsley,S.; Rokhsar,D.S. Sequencing wild and cultivated cassava and related species reveals extensive interspecific hybridization and genetic diversity. Nat Biotechnol. 2016, $34,562-570$.

18. Verde,I.; Abbott,A.G.; Scalabrin,S.; Jung,S.; Shu,S.; Marroni,F.; Zhebentyayeva,T.; Dettori,M.T.; Grimwood,J.; Cattonaro,F.; Zuccolo,A.; Rossini,L.; Jenkins,J.; Vendramin,E.; Meisel,L.A.; Decroocq,V.; Sosinski,B.; Prochnik,S.; Mitros,T.; Policriti,A.; Cipriani,G.; Dondini,L.; Ficklin,S.; Goodstein,D.M.; Xuan,P.; Del fabbro,C.; Aramini,V.; Copetti,D.; Gonzalez,S.; Horner,D.S.; Falchi,R.; Lucas,S.; Mica,E.; Maldonado,J.; Lazzari,B.; Bielenberg,D.; Pirona,R.; Miculan,M.; Barakat,A.; Testolin,R.; Stella,A.; Tartarini,S.; Tonutti,P.; Arús,P.; Orellana,A.; Wells,C.; Main,D.; Vizzotto,G.; Silva,H.; Salamini,F.; Schmutz,J.; Morgante,M.; Rokhsar,D.S. The high-quality draft genome of peach (Prunus persica) identifies unique patterns of genetic diversity, domestication and genome evolution. Nat Genet. 2013, 5, 487-494.

19. Argout,X.; Salse,J.; Aury,J.M.; Guiltinan,M.J.; Droc,G.; Gouzy,J.; Allegre,M.; 
303

304

305

306

307

308

309

310

311

312

313

314

315

316

317

318

319

320

321

322

323

324

325

326

327

328

329

330

331

332

333

334

335

336

337

338

Chaparro,C.; Legavre,T.; Maximova,S.N.; Abrouk,M.; Murat,F.; Fouet,O.; Poulain,J.;

Ruiz,M.; Roguet,Y.; Rodier-goud,M.; Barbosa-neto,J.F.; Sabot,F.; Kudrna,D.;

Ammiraju,J.S.; Schuster,S.C.; Carlson,J.E.; Sallet,E.; Schiex,T.; Dievart,A.; Kramer,M.;

Gelley,L.; Shi,Z.; Bérard,A.; Viot,C.; Boccara,M.; Risterucci,A.M.; Guignon,V.; Sabau,X.; Axtell,M.J.; Ma,Z.; Zhang,Y.; Brown,S.; Bourge,M.; Golser,W.; Song,X.; Clement,D.;

Rivallan,R.; Tahi,M.; Akaza,J.M.; Pitollat,B.; Gramacho,K.; D'hont,A.; Brunel,D.;

Infante,D.; Kebe,I.; Costet,P.; Wing,R.; Mccombie,W.R.; Guiderdoni,E.; Quetier,F.;

Panaud,O.; Wincker,P.; Bocs,S.; Lanaud,C. The genome of Theobroma cacao. Nat Genet.

2011, 43, 101-108.

20. Jaillon o,A.P.; Public Consortium for Grapevine Genome Characterization French-Italian.

The grapevine genome sequence suggests ancestral hexaploidization in major angiosperm

phyla. Nature. 2007, 449, 463-467.

21. Huang,S.; Ding,J.; Deng,D.; Tang,W.; Sun,H.; Liu,D.; Zhang,L.; Niu,X.; Zhang,X.;

Meng,M.; Yu,J.; Liu,J.; Han,Y.; Shi,W.; Zhang,D.; Cao,S.; Wei,Z.; Cui,Y.; Xia,Y.;

Zeng,H.; Bao,K.; Lin,L.; Min,Y.; Zhang,H.; Miao,M.; Tang,X.; Zhu,Y.; Sui,Y.; Li,G.;

Sun,H.; Yue,J.; Sun,J.; Liu,F.; Zhou,L.; Lei,L.; Zheng,X.; Liu,M.; Huang,L.; Song,J.;

Xu,C.; Li,J.; Ye,K.; Zhong,S.; Lu,B.R.; He,G.; Xiao,F.; Wang,H.L.; Zheng,H.; Fei,Z.;

Liu,Y. Draft genome of the kiwifruit Actinidia chinensis. Nat Commun. 2013, 4, 2640.

22. Initiative,A.G. Analysis of the genome sequence of the flowering plant Arabidopsis

thaliana. Nature. 2000, 408, 796-815.

23. Tuskan,G.A.; Difazio,S.; Jansson,S.; Bohlmann,J.; Grigoriev,I.; Hellsten,U.; Putnam,N.;

Ralph,S.; Rombauts,S. The genome of black cottonwood, Populus trichocarpa (Torr. \& Gray). Science. 2006, 313, 1596-1604.

24. Chan,A.P.; Crabtree,J.; Zhao,Q.; Lorenzi,H.; Orvis,J.; Puiu,D.; Melake-berhan,A.;

Jones,K.M.; Redman,J.; Chen,G.; Cahoon,E.B.; Gedil,M.; Stanke,M.; Haas,B.J.;

Wortman,J.R.; Fraser-liggett,C.M.; Ravel,J.; Rabinowicz,P.D. Draft genome sequence of the oilseed species Ricinus communis. Nat Biotechnol. 2010, 28, 951-956.

25. Goff,S.; Ricke,D.; Lan,T.H.; Presting,G.; Wang,R.; Dunn,M.; Glazebrook,J.; Sessions,A.;

Oeller,P.; Varma,H.; Hadley,D.; Hutchison,D.; Martin,C.; Katagiri,F.; Lange,B.M.;

Moughamer,T.; Xia,Y.; Budworth,P.; Zhong,J.; Miguel,T.; Paszkowski,U.; Zhang,S.;

Colbert,M.; Sun,W.L.; Chen,L.; Cooper,B.; Park,S.; Wood,T.C.; Mao,L.; Quail,P.;

Wing,R.; Dean,R.; Yu,Y.; Zharkikh,A.; Shen,R.; Sahasrabudhe,S.; Thomas,A.;

Cannings,R.; Gutin,A.; Pruss,D.; Reid,J.; Tavtigian,S.; Mitchell,J.; Eldredge,G.; Scholl,T.;

Miller,R.M.; Bhatnagar,S.; Adey,N.; Rubano,T.; Tusneem,N.; Robinson,R.; Feldhaus,J.;

Macalma,T.; Oliphant,A.; Briggs,S. A draft sequence of the rice genome (Oryza sativa L.

ssp. japonica). Science. 2002, 296, 92-100. 
339 26. Yotoko,K.S.; Dornelas,M.C.; Togni,P.D.; Fonseca,T.C.; Salzano,F.M.; Bonatto,S.L.;

Table 1 The annotation cultivated passion fruit genome.

\begin{tabular}{lll}
\hline Database & Annotated Num & Annotated Percent $(\%)$ \\
\hline NR & 22062 & 95.7 \\
Swiss-Prot & 17974 & 78 \\
KEGG & 16835 & 73 \\
InterPro & 20786 & 90.2 \\
Pfam & 15341 & 66.5 \\
GO & 11108 & 48.2 \\
Annotated & 22200 & 96.3 \\
Total & 23053 & - \\
\hline
\end{tabular}

Table 2 Genes used for gene family clustering in nine species.

\begin{tabular}{lcccccc}
\hline \multicolumn{1}{c}{ Species } & $\begin{array}{c}\text { Genes } \\
\text { number }\end{array}$ & $\begin{array}{c}\text { Genes in } \\
\text { families }\end{array}$ & $\begin{array}{c}\text { Unclustered } \\
\text { genes }\end{array}$ & $\begin{array}{c}\text { Family } \\
\text { number }\end{array}$ & $\begin{array}{c}\text { Unique } \\
\text { families }\end{array}$ & $\begin{array}{c}\text { Average genes } \\
\text { per family }\end{array}$ \\
\hline $\begin{array}{l}\text { Arabidopsis } \\
\text { thaliana }\end{array}$ & 48321 & 44484 & 3837 & 15029 & 2081 & 2.96 \\
Theobroma & 30854 & 29472 & 1382 & 15251 & 439 & 1.93
\end{tabular}


bioRxiv preprint doi: https://doi.org/10.1101/522128; this version posted January 16,2019 . The copyright holder for this preprint (which was not certified by peer review) is the author/funder, who has granted bioRxiv a license to display the preprint in perpetuity. It is made available under aCC-BY-NC-ND 4.0 International license.

\begin{tabular}{|c|c|c|c|c|c|c|}
\hline $\begin{array}{l}\text { Actinidia } \\
\text { chinensis }\end{array}$ & 33115 & 29260 & 3855 & 14583 & 629 & 2.01 \\
\hline $\begin{array}{l}\text { Populus } \\
\text { trichocarpa }\end{array}$ & 51717 & 49631 & 2086 & 15441 & 797 & 3.21 \\
\hline $\begin{array}{l}\text { Prunus } \\
\text { persica }\end{array}$ & 47089 & 42308 & 4781 & 15830 & 1115 & 2.67 \\
\hline Vitis vinifera & 29927 & 21929 & 7998 & 14789 & 729 & 1.48 \\
\hline $\begin{array}{l}\text { Ricinus } \\
\text { communis }\end{array}$ & 28584 & 26580 & 2004 & 15009 & 329 & 1.77 \\
\hline Oryza sativa & 42132 & 28555 & 13577 & 13886 & 2587 & 2.06 \\
\hline $\begin{array}{l}\text { Passiflora } \\
\text { eduis }\end{array}$ & 23053 & 12767 & 10286 & 9868 & 291 & 1.29 \\
\hline
\end{tabular}

363

364

365

366

367

368

369

370

371

372

373

374

375

376

377

378

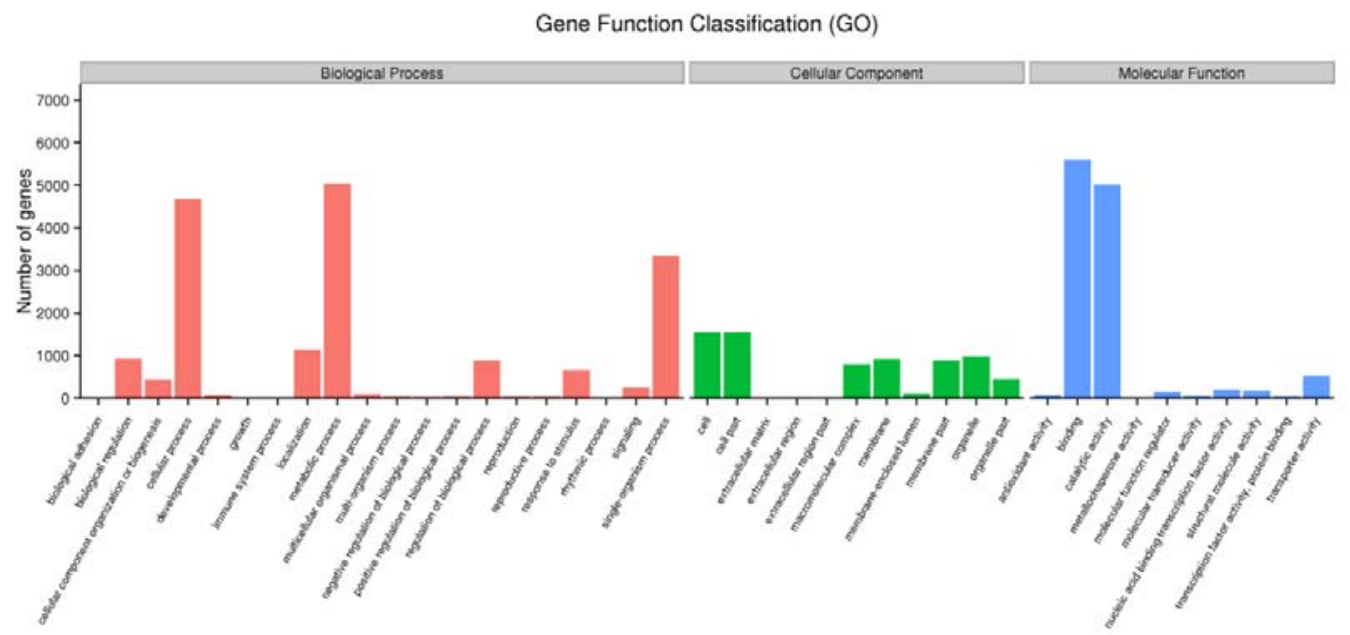

379

380 Figure 1. GO function analysis of the annotated genes.

381

382 
bioRxiv preprint doi: https://doi.org/10.1101/522128; this version posted January 16,2019 . The copyright holder for this preprint (which was not certified by peer review) is the author/funder, who has granted bioRxiv a license to display the preprint in perpetuity. It is made available under aCC-BY-NC-ND 4.0 International license.

383

384

385

386

387

388

389

390

391

392

393

394

395

396

397

398

399

KEGG Classification

400

401

402

403

404

405

406

407

408

409

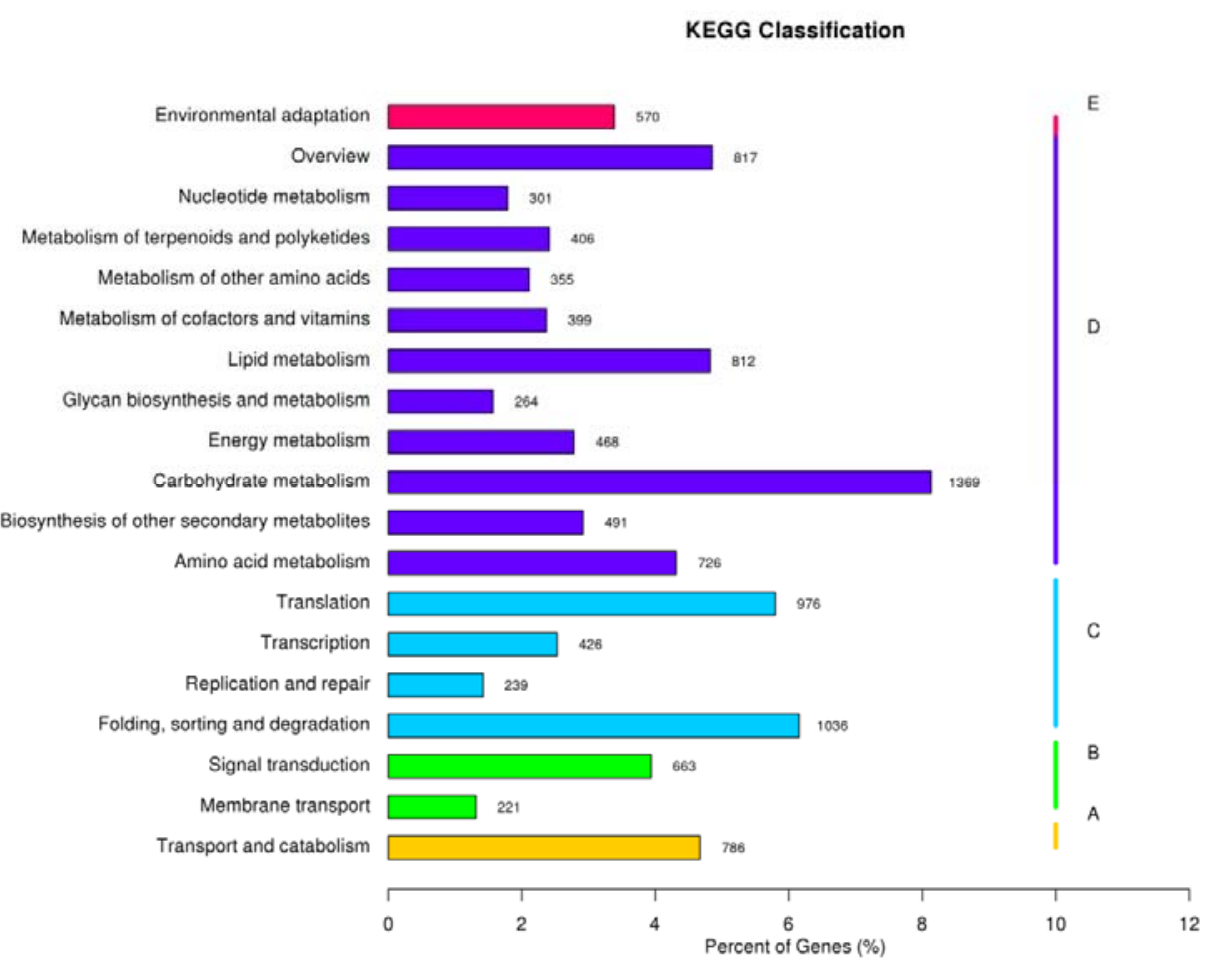


bioRxiv preprint doi: https://doi.org/10.1101/522128; this version posted January 16,2019 . The copyright holder for this preprint (which was not certified by peer review) is the author/funder, who has granted bioRxiv a license to display the preprint in perpetuity. It is made available under aCC-BY-NC-ND 4.0 International license.

410

411

412 Figure 2. Pathway classification of the annotated genes.

413

414

415

416

417

418

419

420

421

422

423

424

425

426

427

428

429

430

431

432

433

434

435

436

437

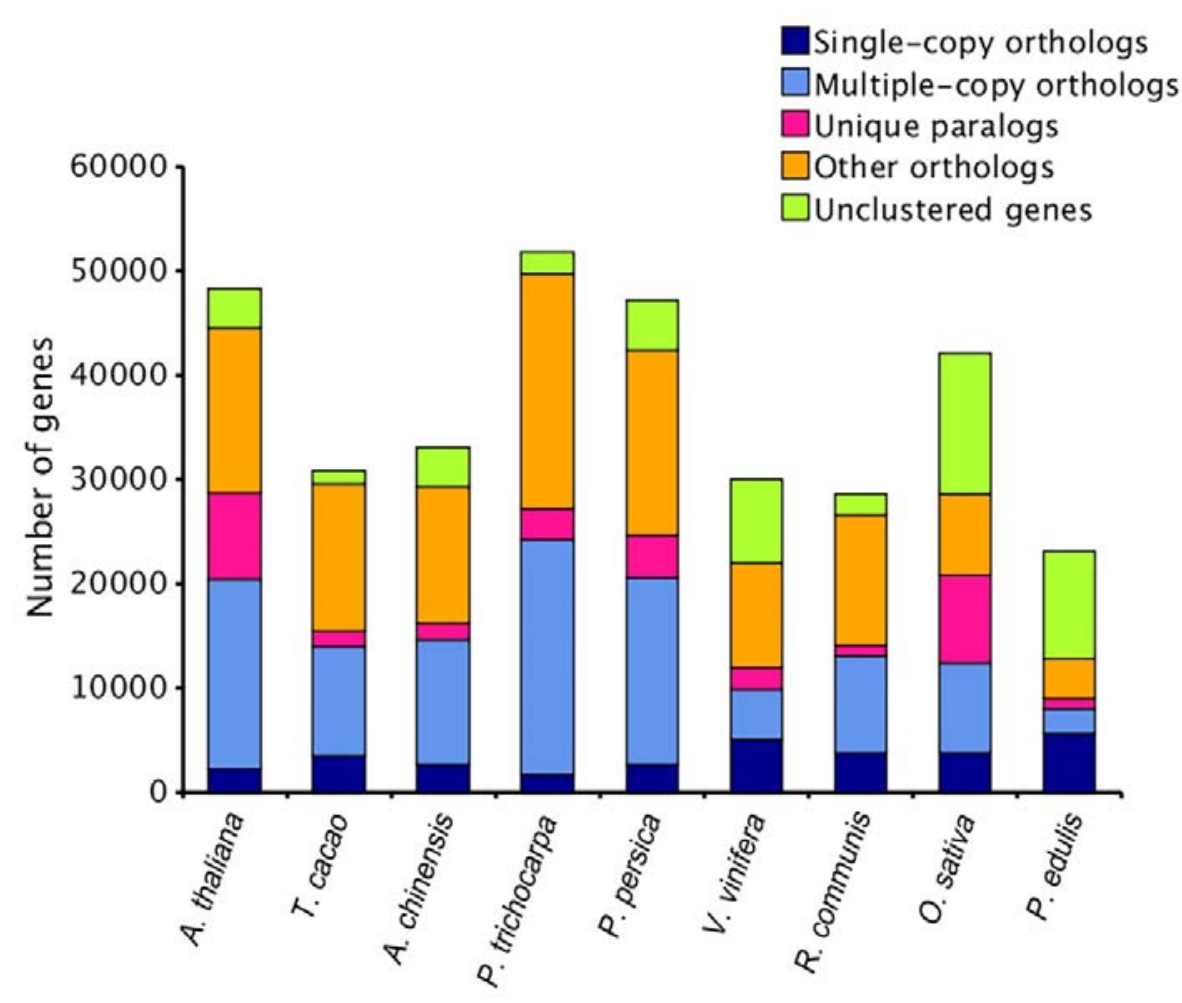


bioRxiv preprint doi: https://doi.org/10.1101/522128; this version posted January 16,2019 . The copyright holder for this preprint (which was not certified by peer review) is the author/funder, who has granted bioRxiv a license to display the preprint in perpetuity. It is made available under aCC-BY-NC-ND 4.0 International license.

440 Figure 3. Gene family clustering in 9 species.

441

442

443

444

445

446

447

448

449

450

451

452

453

454

455

456

457

458

459

460

461

462

463

464

465

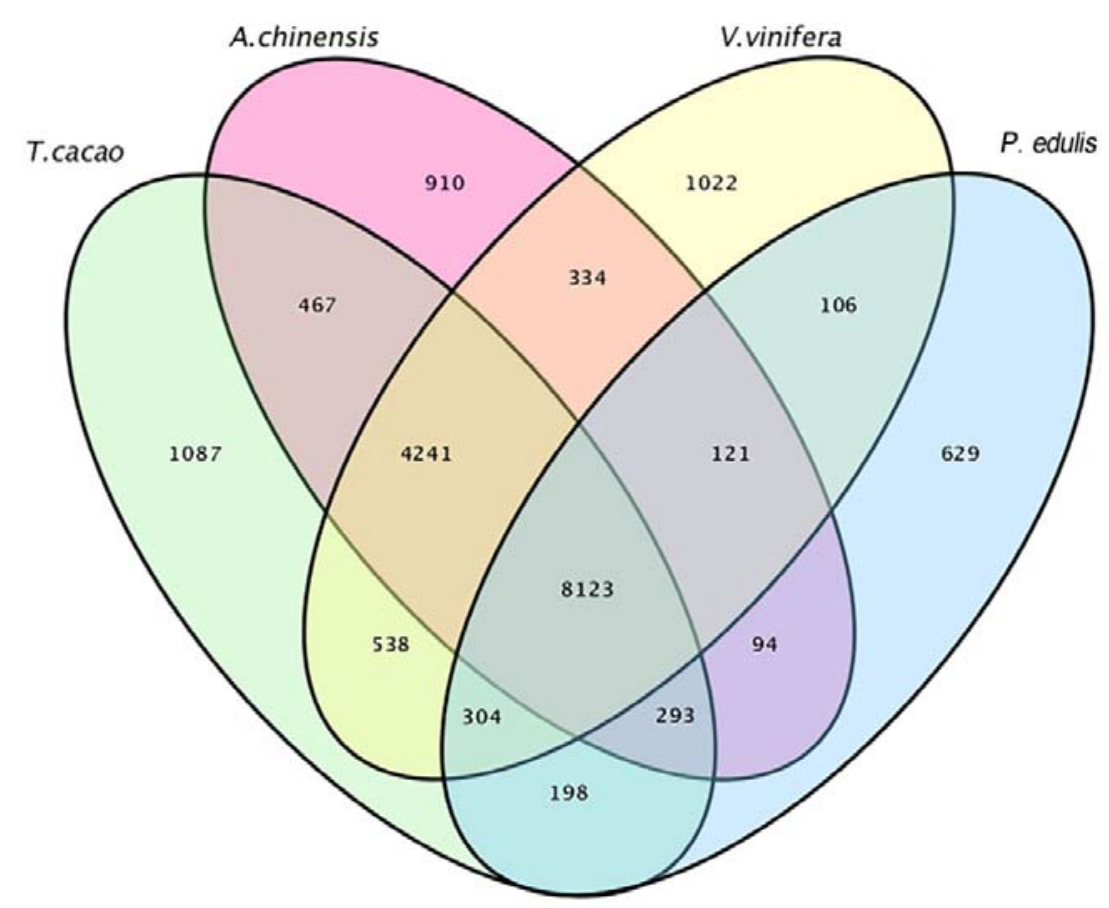


bioRxiv preprint doi: https://doi.org/10.1101/522128; this version posted January 16,2019 . The copyright holder for this preprint (which was not certified by peer review) is the author/funder, who has granted bioRxiv a license to display the preprint in perpetuity. It is made available under aCC-BY-NC-ND 4.0 International license.

466

467

468

469 Figure 4. Homology analysis in 4 species.

470

471

472

473

474

475

476

477

478

479

480

481

482

483

484

485

486

487

488

489

490

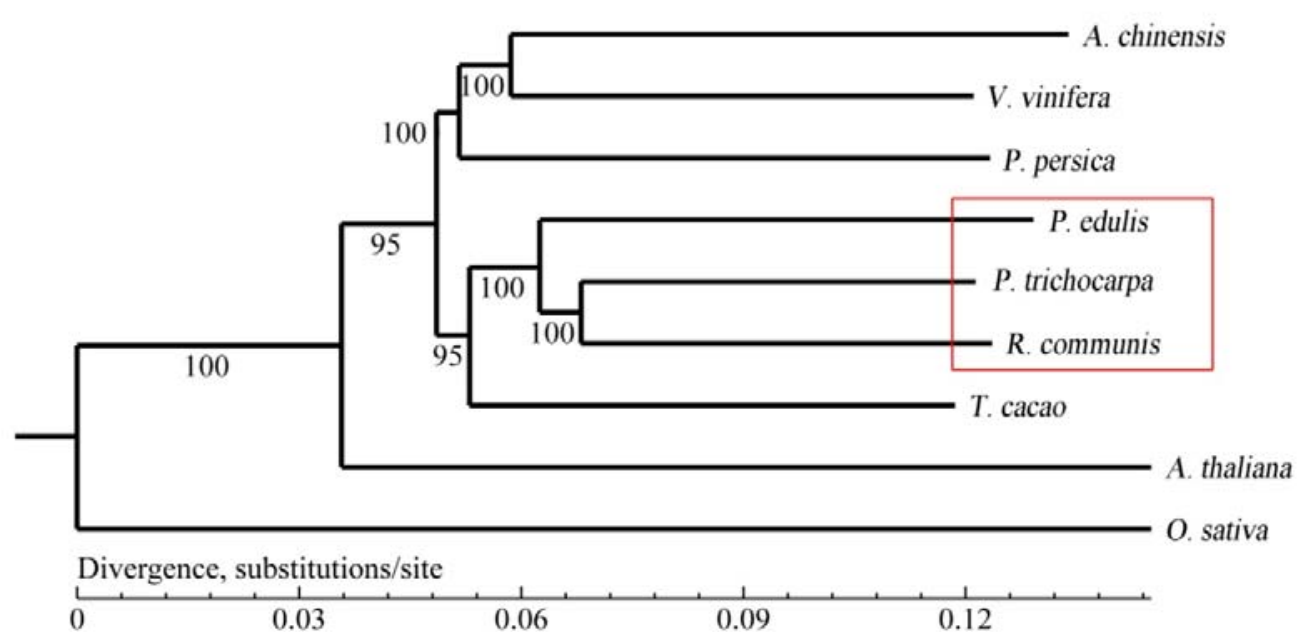

491

492 Figure 5. Phylogenetic analysis of 9 species.

493 
bioRxiv preprint doi: httos://doi org/101101/522128: this version posted January 16 2019. The copvriaht holder for this preprint (which was not certified by peer review) is the author/funder, who has granted bioRxiv a license to display the preprint in perpetuity. It is made available under aCC-BY-NC-ND 4.0 International license.

494

495

496 
Gene Function Classification (GO)
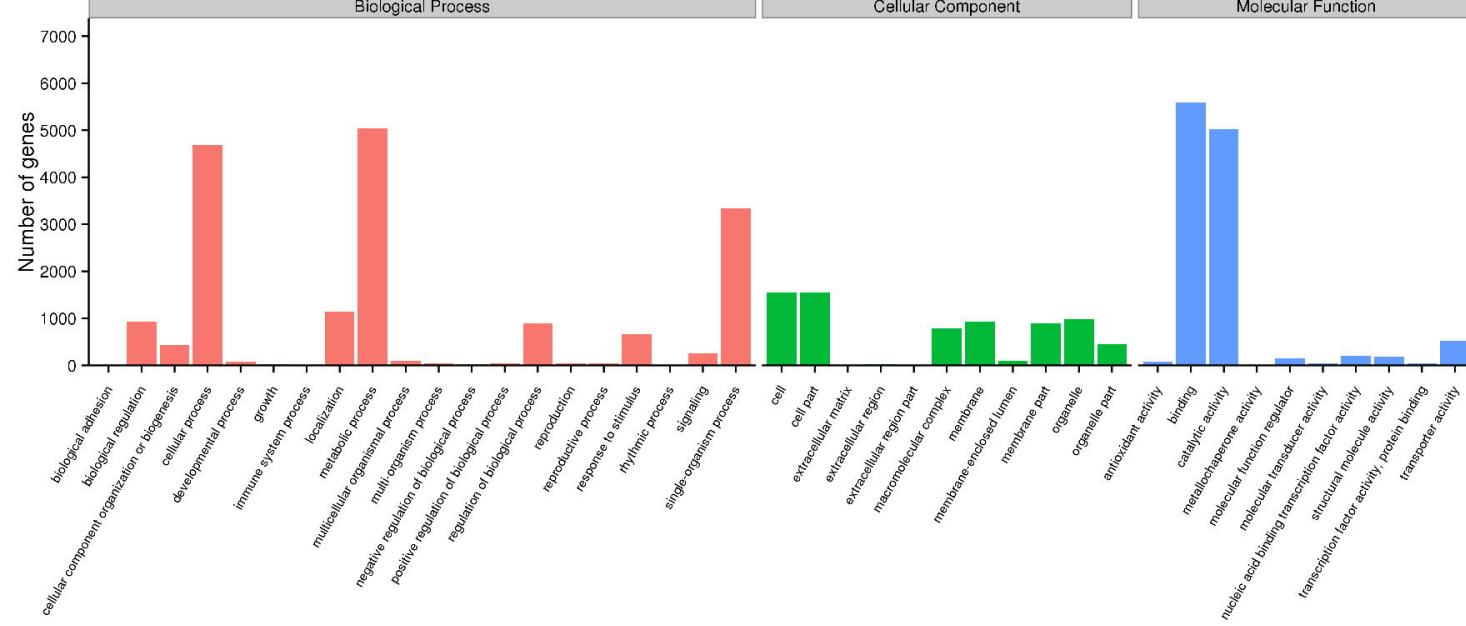


\section{KEGG Classification}

\section{Environmental adaptation}

Overview

Nucleotide metabolism

Metabolism of terpenoids and polyketides

Metabolism of other amino acids

Metabolism of cofactors and vitamins

Lipid metabolism

Glycan biosynthesis and metabolism

Energy metabolism

Carbohydrate metabolism

Biosynthesis of other secondary metabolites

Amino acid metabolism

Translation

Transcription

Replication and repair

Folding, sorting and degradation

Signal transduction

Membrane transport

Transport and catabolism

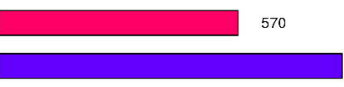

817

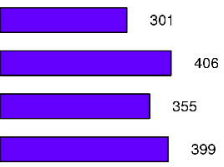

399

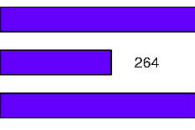

812

468

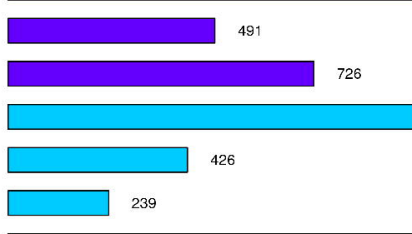

976

1036

663

221

786

\begin{tabular}{|c|c|c|c|c|c|c|}
\hline Г & $T$ & $T$ & $T$ & $T$ & $T$ & \\
\hline 0 & 2 & 4 & 6 & 8 & 10 & 12 \\
\hline
\end{tabular}









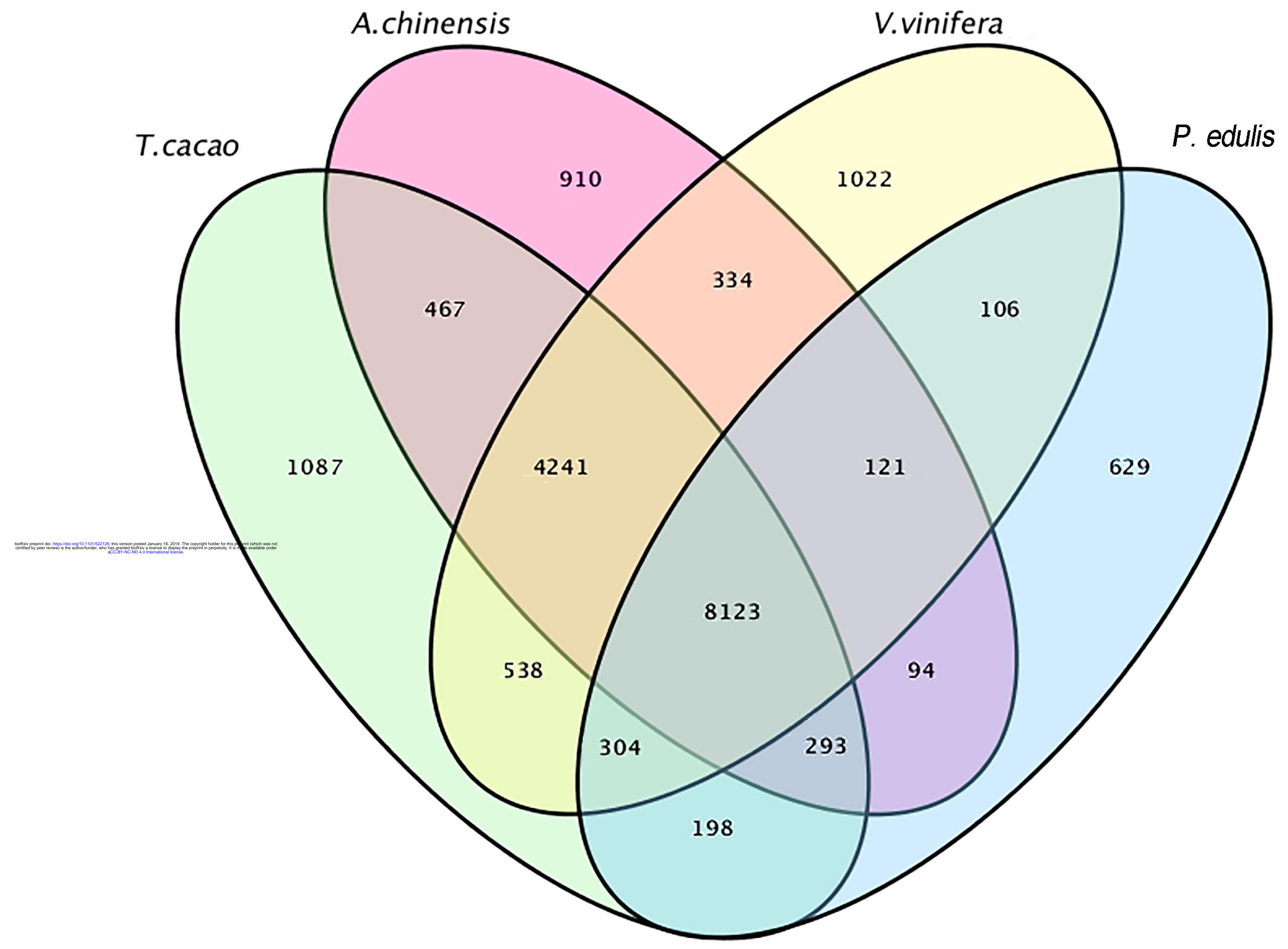




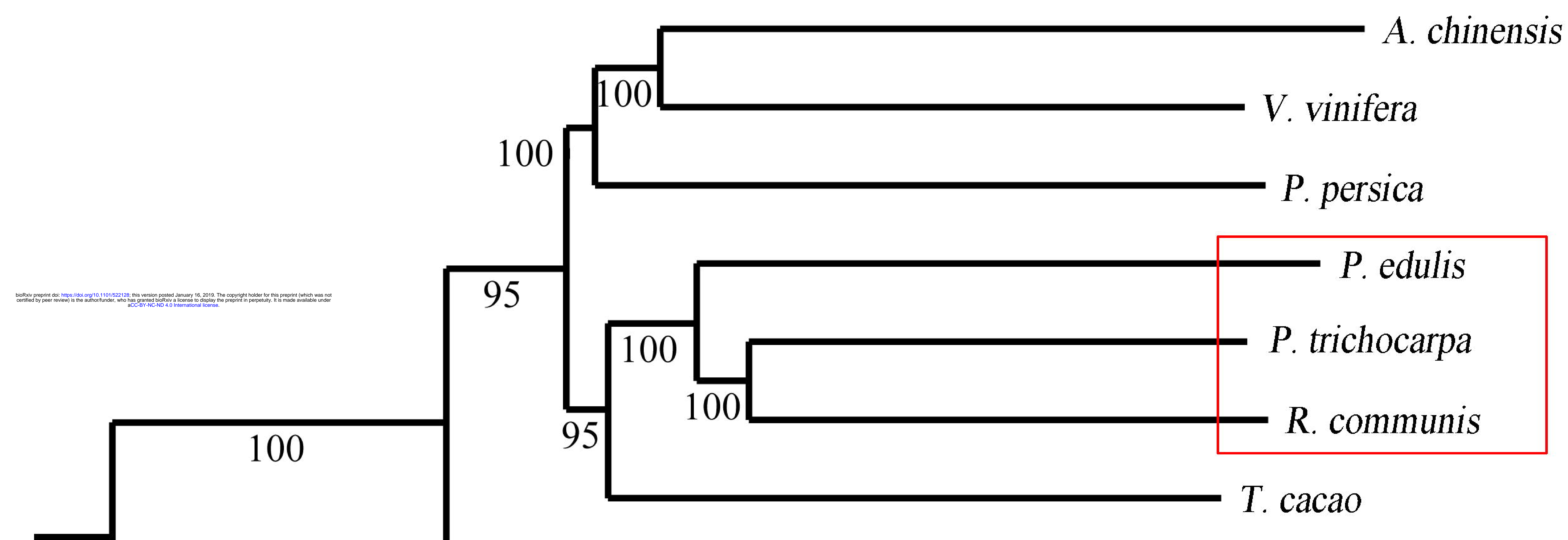

A. thaliana

O. sativa

Divergence, substitutions/site

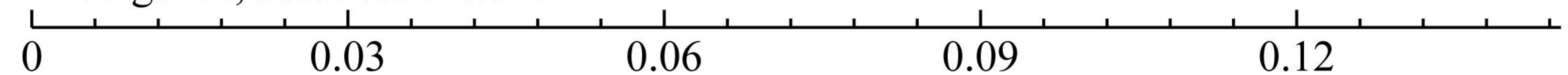

